\title{
Papilar topografy and morphology of the tongue in the
}

\section{E. sexcinctus}

\author{
SILVA, A. B. S. ${ }^{1 *}$, CAVALCANTE, M. M. A. S. ${ }^{1}$, FERRAZ, M. S. ${ }^{2}$, \\ RIZZO, M. S. ${ }^{2}$, FORTES, E. A. M. ${ }^{2}$, CUNHA, B. M. ${ }^{1}$, CARVALHO, M. A. M. ${ }^{3}$ \\ and CONDE JÚNIOR, A. M.²
}

\begin{abstract}
${ }^{1}$ Laboratory Histotechnique, Sciences and Helth Mester Program Student, Department of Morphology, Universidade Federal do Piauí - UFPI, Campus Universitário Ministro Petrônio Portella, Av. Universitária, Ininga, CEP 64049-550, Teresina, PI, Brazil

${ }^{2}$ Laboratory Histotechnique, Department of Morphology, Universidade Federal do Piauí - UFPI, Campus Universitário Ministro Petrônio Portella, Av. Universitária, Ininga, CEP 64049-550, Teresina, PI, Brazil

${ }^{3}$ Department of Veterinary Morphophysiology, Center for Research of Stem Cells, Universidade Federal do Piauí - UFPI, Campus Universitário Ministro Petrônio Portella, Av. Universitária, Ininga, CEP 64049-550, Teresina, PI, Brazil *E-mail: andrezzabl@hotmail.com
\end{abstract}

\begin{abstract}
Introduction: The Six-banded armadillo (Euphractus sexcintus) belongs to Cigunlata order, has diverse feeding habits and masticatory apparatus developed. The tongue, one of the major components of this equipment, has the mucosa papillae, taste buds and tongue glands. Materials and Methods: Six-banded armadillo were submitted to an anesthetic protocol with Tiletamine and zolazepan (Telazol ${ }^{\circledR}$, Fortdotge, Brazil) and Sodium Thiopental (Thiopentax ${ }^{\circledR}$, Cristália, Brazil), we proceeded to euthanasia using Potassium Chloride $19.1 \%$, to then fix them in a $10 \%$ formaldehyde solution. The tongues were dissected and identified structures. For microscopic processing, segments from different parts of the tongue were subjected to histological routine and stained with hematoxylin-eosin and Masson. Results: The tongue of the six-banded armadillo presents three types of papillae: filiform, fungiform and vallate, with no conical buds and foliate. Still in the tongue mucosa, was observed mucous glands and various taste corpuscles. Some data differ from those same found in other wild animals that have been studied, but are similar to those of the same phylogenetic. Conclusion: The morphological characteristics of the six-banded armadillo's tongue are adapted to the difficulties faced by him during chewing, requiring the tongue, structures that provide you mobility, strength and sensitivity.
\end{abstract}

Keywords: Euphractus sexcinctus, tongue, papillae, six-banded armadillo.

\section{Introduction}

The superorder Xenarthra comprises a representative group of the fauna of the Americas, which has morphology and ecological specializations distinct (ZIMBRES, 2010). Armadillos (Cigunlata order), anteaters and sloths (Pilosa order) component the three xenarthrics biological models existing in the Brazilian fauna (FISCHER, PETROCHI, SANTOS, et al., 2011). The 'Cingulata' name refers to the body covered by mobile structures called bands or girdles, this feature is essential to differentiate the species of armadillos (PEREIRA JUNIOR, 2007).

Regardind your intense exploration armadillos have been exploited by humanity as a source of food, traditional medicine, income and still used in popular beliefs (BARBOZA, 2009). These practices contribute to include more dasipodídeos of cigunlata order in the endangered animals list of extinction (NASCIMENTO and CAMPOS, 2011). The members of this family usually have nocturnal activity and they are difficult to be visualized and captured. These factors hinder the studies and contribute to the lack of ecological information available for the group (MCDONOUGH and LOUGHRY, 2008).
As the largest representative of the genre Euphractus and Dasypodidae family member, the Euphractus sexcinctus or six-banded armadillo receive this designation to present six mobile girdles (ALBERTO, OLIVEIRA, RODRIGUES et al., 2010). They are solitary animals, except in reproductive ages, and different from the rest of his family have predominantly diurnal and crepuscular habits digging underground burrows in search of shelter and food (MEDRI, MOURÃO and MARINHO-FILHO, 2009).

The habit of digging also assists in the six-banded armadillo feeding process, since it uses its claws and smell developed to look for food in the basement (ALBERTO, OLIVEIRA, RODRIGUES et al., 2010). They are considered omnivores, having a diet that goes from plant material, invertebrates, carcass of dead animals, even small vertebrates such as frogs, snakes, birds and rodents (DALPONTE and TAVARES FILHO, 2004).

The nutrition six-banded Armadillo is varied, consisting of elements that have a wide variation in the energy levels, but his body only absorbs a small amount of it is consumed in his feeding, since their basal metabolic rate is low, which 
contributes to reduce a number of problems that they face the body from overheating during excavation (MCNAB, 1984).

Moreover, the elements ingested by six-banded armadillo present shape, size and varying consistency, aspects that lead the animal to present a tough masticatory apparatus. For this, the six-banded armadillo has a dentition more pronounced when compared to other armadillo species, presenting developed muscle bundles of the face, plus a relatively short snout attributes that favor a greater bite force (SMITH and REDFORD, 1990).

Even so, the movement exerted by face of Armadillo during the chewing also provides better grinding of food, and an organ which is directly related to this is the tongue. The morphological characteristics of the tongue of all animals reflect aspects of diet and digestion of food (SMITH and REDFORD, 1990; DALPONTE and TAVARES FILHO, 2004).

The tongue comprises an organ of the digestive system that moves the food in the oral cavity, causing it to move up the face of teeth eruption and directing it towards the throat to be swallowed. Apart from that relates to taste due to the presence of taste buds on the surface and participates in some animals vocalization. And also relates to the production of secretions, since it presents between the muscle bundles, serous and mucous glands (DU TOIT, 2003).

To perform the mechanical and gustatory function during chewing, the tongue also has a series of tongue papillae, keratinized variably distributed around its surface. In all, one can describe five papillae: filiform, vallate, foliaceous, lenticular or conical; and is found in different forms between species (BANKS, 1991; HIB, 2001).

In order to enrich the Brazilian literature with attributes about our fauna, this study aims to examine the tongue mucosa of six-banded armadillo (Euphractus sexcinctus) highlighting morphological aspects of their lingual papillae. And with that, gather the results analyzed in this species to compare with other species of the same eating habits and / or phylogenetic same.

\section{Materials and Methods}

This study was conducted at the Federal University of Piauí (UFPI) in Histotechnique Laboratory of Morphology Department of the Health Sciences Center (CCS). Ten six-banded armadillos were used (Euphractus sexcinctus) from predatory hunting and seized by the Chico Mendes Institute for Biodiversity (ICMBio) and forwarded to UFPI for scientific purposes. The animals were kept in an enclosure with water and diet, for collection of biological material and additional information such as gender, taxonomic classification, age and weight.

The animals were pre-anesthetized with Tiletamine and zolazepam at a dose of $15 \mathrm{mg} / \mathrm{kg}$ intramuscularly in the hind limb. There has been induced with sodium thiopental at $40 \mathrm{mg} / \mathrm{kg}$ intraperitoneally and after reaching the deep anesthesia was injected an ampoule of potassium chloride $19.1 \%(10 \mathrm{ml})$ via intracardiac. The animals were cannulated and fixed in 10\% formaldehyde solution. For the macroscopic, the tongues were extracted, dissected, removed from the oral cavity and the structures identified were classified schematically drawn, analyzed and photo documented in a Sony ${ }^{\circledR}$ digital camera, DSC 100 model.

For microscopic processing segments from different parts of the tongue (apex body and root) were cut and immersed in $70^{\circ}$ ethanol solution. Subsequently the material was dehydrated in a series of increasing concentrations of ethanols $(70 \%$ to $100 \%$ ), diaphanized in xylene, followed by paraffin embedding (Histosec $^{\circledR}$, Merck, Lot: K91225309) cut in the microtome (Leica RM 2165) with average thickness of 4 microns (micrometers). Subsequently the sections were stained with hematoxylin eosin (HE) and Masson (TM), mounted with Entelan ${ }^{\circledR}$ and cover slips. The microscopic photo documentation was made using a light microscope Leica DM 2000 and the nomenclature used was reported as International Comittee on Veterinary Gross Anatomical Nomenclature (2005).

\section{Results}

The tongue of six-banded armadillo has an elongated and thin shape that narrows towards the apex. In length, the values were close to eight centimeters. Their dorsal surface was found to be irregular with some increases in contrast to the ventral surface smooth and flat.

The lingual surface of the armadillo-six-banded presents three types of papillae: filiform, fungiform and vallate, and the absence of conical papillae and foliate papillae. Among all, the filiform are the most abundant and distributed over the entire surface on the side including the tongue. The fungiform papillae, they stand randomly among the filiform papillae, so that number will increase as they move away from the apex. The vallate papillae, were only the sides of the body and root forming a row (Figure 1).

The histological aspects revealed that the lingual surface of six-banded armadillo presents lined by numerous filiform facing the caudal portion of the tongue, supported by connective tissue with connective projections for the epithelium in various ways. The filiform papillae have thorny aspect, do not have taste buds and they are lined by stratified squamous epithelium keratinized (Figure 2a, b).

The fungiform papillae of the six-banded armadillo show the histological aspect oval cuts, with wide base and a concave apex that to emerge from the mucosa had a stratum corneum of coating consisting of keratinized cells and dead cells. It also has on average two or three taste buds at the base, which tend to disorganize as the papilla undergoes maturation. Adjacent to the mucosa is the connective tissue with connective projections of fungiform aspect (Figure 2e, f).

The vallate papillae, as the name suggests, located within a depression lingual epithelium, protruding slightly above the surface of the tongue, with some taste corpuscles in its side wall. Are coated in six-banded armadillo by stratified squamous keratinized epithelium and have rectangular aspect with a narrow base (Figure $2 \mathrm{~g}$ ).

Distributed over the entire length of the dorsal surface of the tongue six-banded armadillo were observed gustatory corpuscles or taste buds, sometimes isolated, sometimes attached to fungiform and vallate papillae, being in its constitution. When are isolated can perceive the presence of various connective projections of varying formats (Figure $2 c, d$ ).

In the caudal region of six-banded armadillo tongue was noted lot of acini of lingual glands type mucous disposed between the muscle fiber bundles (Figure 2h). Not observed serous glands. 

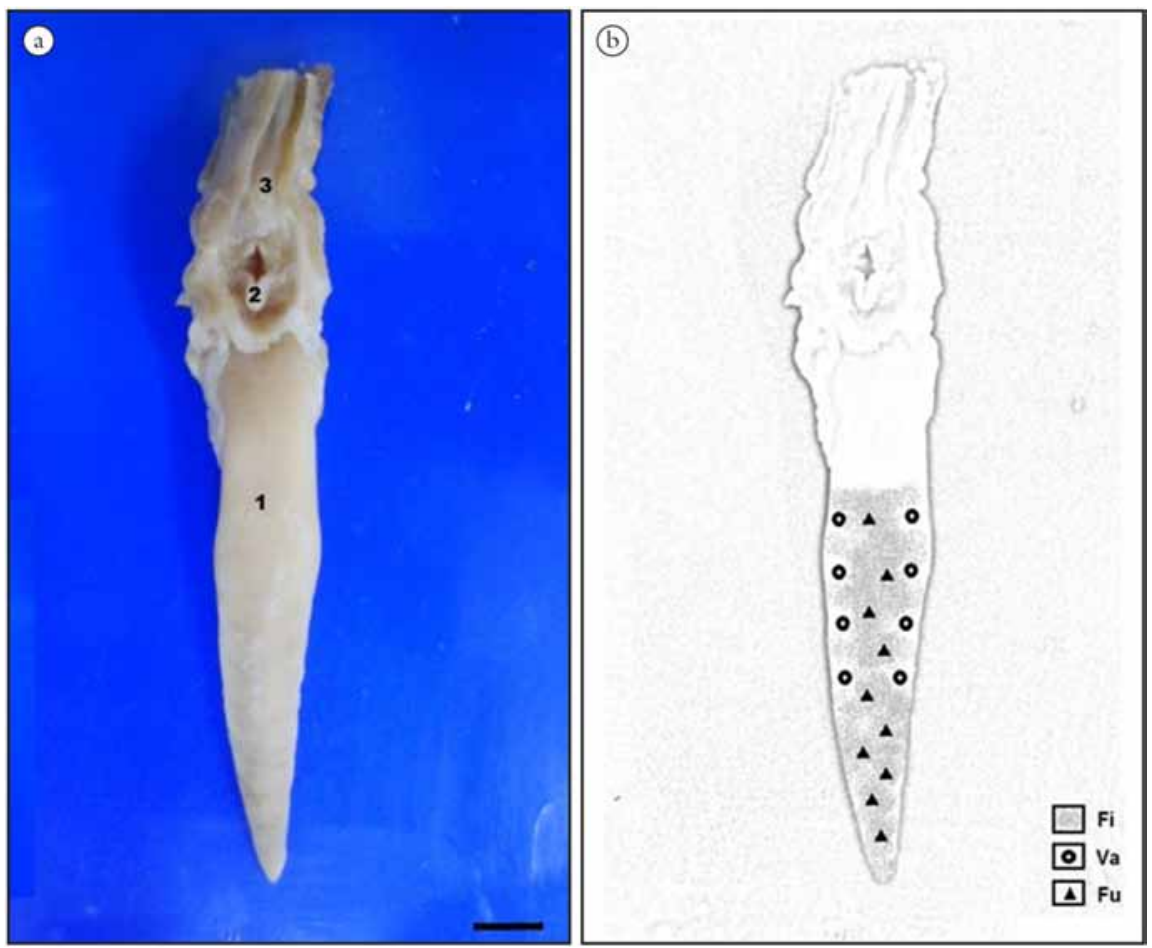

Figure 1. Photographs showing the language-larynx-esophagus cranial set six banded armadillo (Euphractus sexcinctus). Legend: In the photo notes the tongue (1), the larynx (2) and the esophagus (3). In the drawing can be noted the distribution of the filiform papillae (Fi), fungiform $(\mathrm{Fu})$ and vallate $(\mathrm{Va})$ on the lingual surface. Bar: $1 \mathrm{~cm}$.
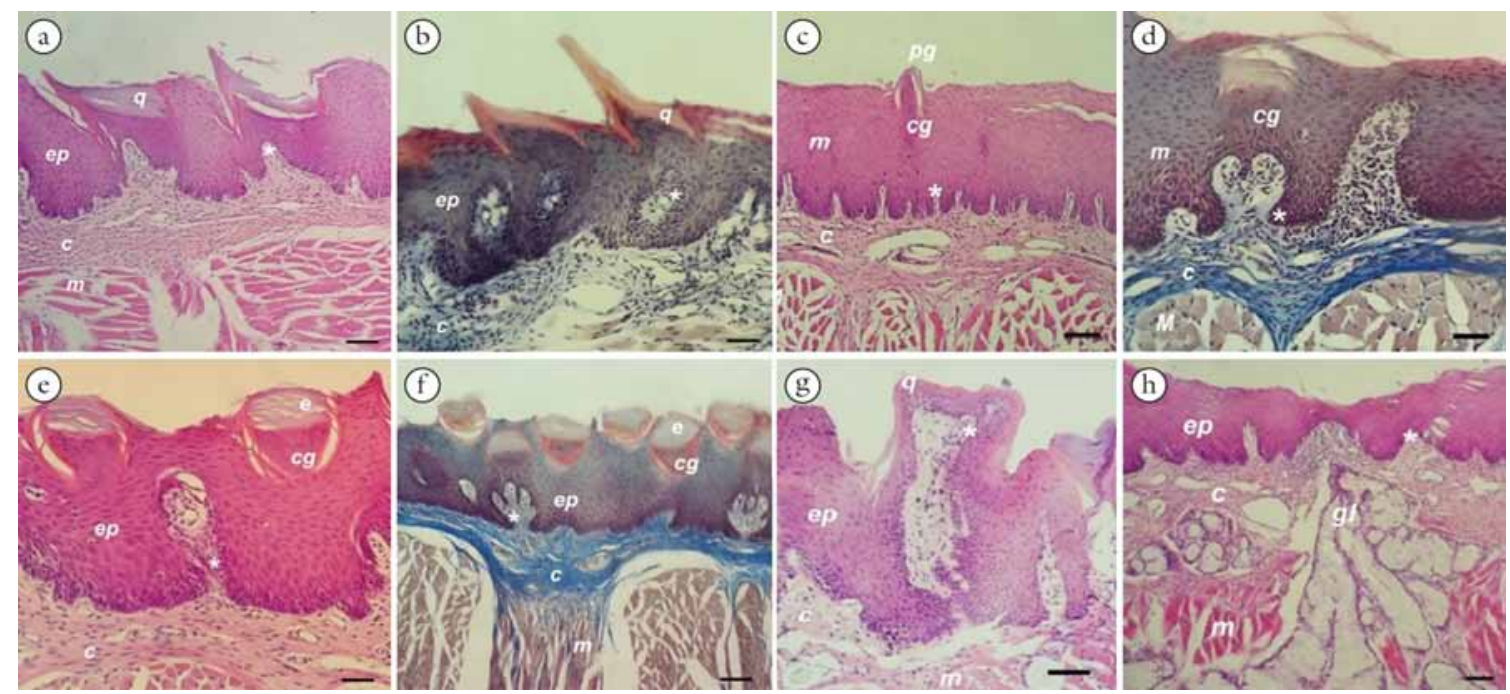

Figure 2. Photomicrographs of the papilar topografy and the morphology of the tongue in the Euphractus sexcinctus. We can observed the cross section of the filiform papillae with Hematoxilin-eosin (a) and Masson's tricromic staining (b). Bar: $50 \mu \mathrm{m}(20 \mathrm{x})$. The cross-section of the tongue taste corpuscles with Hematoxilin-eosin (c) and Masson's tricromic staining (d). Bar: 50 microns (20x). The cross section of the fungiform papillae with Hematoxilin-eosin (e, Bar $50 \mu \mathrm{m} \mathrm{20x}$ ) and Masson's tricromic staining (f, $100 \mu \mathrm{m}$ 10x). The cross section of vallate papilla with hematoxilin-eosin staining (g, Bar: $20 \mu \mathrm{m} \mathrm{10x}$ ). The cross section of the mucous

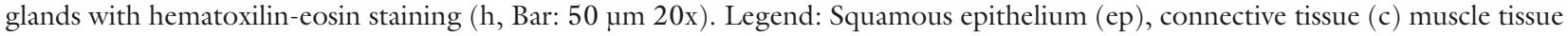
$(\mathrm{m})$, keratinized tissue $(\mathrm{q})$, taste corpuscles $\left({ }^{*}\right)$, corpuscle papilla $(\mathrm{cg})$, stratum corneum (e), taste pore (pg) and mucous glands $(\mathrm{gl})$.

\section{Discussion}

The three types of lingual papillae (filiform, fungiform and vallate) found in six-banded armadillo were also observed in other species of armadillos by researchers as Ciuccio, Estecondo and Casanave (2010) and Moraes, Watanabe and
Konig Junior (1994). As for the distribution in these species, the fungiform and filiform followed the same distribution observed in six-banded armadillo but the vallate papillae were restricted to the root. Menezes, Kaminishi, Vieira et al (2013) studied the lingual surface rabbits (Oryctolagus cuniculus) 
noted the presence of a fourth papilla, the foliácea, that the analyzed samples do not have. Have the coati (Nasua nasua) rather than foliácea has conical buds to complement the mechanical function of the filiform papillae (SOUZA, OLIVEIRA, SANTOS et al., 2012).

It is known that the power of the armadillos and the coati is similar but the coati eat more roughage compared to food diet. Thus, this fact explains the existence of an increase in mechanical digestion demonstrated by the presence of two mechanical papillae (conical and filiform) in the tongue of coatis, unlike armadillos because they have only vegetable based diet, fruits and small invertebrates eventually requires not more than one type of mechanical papilla, in the case filiform, to digestion (DALPONTE and TAVARES FILHO, 2004; MENEZES, KAMINISHI, VIEIRA et al., 2013).

The filiform papillae are mechanical and presenting a stratified epithelium with varying between species (BACHA and BACHA, 2003). This epithelium in rabbits (Oryctolagus oructolagus) and three-toed sloth (Bradypus torquatus) presented a more consistent compared to the same being histologically similar six-banded armadillo. The thickness of the squamous epithelium on the filiform papillae on the tongue surface can confer greater protection from abrasion and penetration chemical and physical agents, and low fluid loss (JUNQUEIRA and CARNEIRO, 2005; BENETTI, 2005; SOUZA, OLIVEIRA, SANTOS et al., 2012; MENEZES, KAMINISHI, VIEIRA et al., 2013).

Unlike fungiform papillae which has a greater mechanical function, fungiform papillae provides for the recognition of flavors present normally in its constitution taste corpuscles (JUNQUEIRA and CARNEIRO, 2005). In animals such as coati, this papilla was shown to be similar to the same -six-banded armadillo, but compared to sloths and rabbit showed differences in the way, since the appearance of the papilla in these animals is circular and the base the rabbit is narrow. However, the three animal models (rabbit, coati and sloth) have taste buds in the constitution of fungiform papillae, with the exception of coati (BENETTI, 2005; SOUZA, OLIVEIRA, SANTOS et al., 2012; MENEZES, KAMINISHI, VIEIRA et al., 2013).

Another papilla found in -six-banded armadillo, the vallate express likeness to vallate papilla of the rabbit and differences with them in coati and sloths (BENETTI, 2005; SOUZA, OLIVEIRA, SANTOS et al., 2012; MENEZES, KAMINISHI, VIEIRA et al., 2013). In coati can observe the presence of salivary ducts opening on the vallate papilla, a fact that has not been seen in six-banded armadillo (SOUZA, OLIVEIRA, SANTOS et al., 2012). Moreover, the taste corpuscles of vallate papilla sloth located only in the surface portion, as six-banded armadillo as they may be in both the lateral and the surface (BENETTI, 2005).

Both in fungiform as in vallate papillae of the six-banded armadillo were observed gustatory corpuscles, which as the name suggests, gives flavor to food. We could see the same cell arrangement at all observed gustatory corpuscles, both isolated as those who are part of the constitution of the papillae. The characterization of taste corpuscles match the description made by Banks (1991), Bacha and Bacha (2003) and Ross (2008), highlighting the importance of these corpuscles in the sensation of flavor of the food to define a diet. The absence or malfunction of these corpuscles can generate a disturbance of feeling of the tongue hindering the recognition of flavors with this, there would be less selectivity on the part of the animal in choosing what he will eat.

Besides taste buds and corpuscles, the lingual mucosa also has lingual glands type mucous, serous or mixed. However, the six-banded armadillo presents lingual glands type mucous only reported also in sloth, as well as the coati mucous met serous glands and salivary (BENETTI, 2005; SOUZA, OLIVEIRA, SANTOS et al., 2012). The importance of the mucous glands is the role played by their secretions to maintain the existing crypts in the root of the lingual epithelium free of food debris and residues (HIB, 2001).

\section{Conclusion}

The morphological features found in the tongue of six-banded armadillo adapt to the difficulties faced in oral digestion during chewing, which requires the tongue, structures that provide you mobility, strength and sensitivity.

Acknowledgements: At Federal University of Piaui and Chico Mendes Institute for Biodiversity (ICMBio).

\section{Reference}

ALBERTO, MLV., OLIVEIRA, CM., RODRIGUES, MN., OLIVEIRA, AB., MIGLINO, MA. and AMBRÓSIO, CE. Funçoes ósseas do esqueleto de tatu (Euphractus sexcinctus). Acta Veterinaria Brasilica, 2010, vol. 4, n. 2, p. 86-91.

BACHA, WJ. and BACHA, LM. Atlas colorido de histologia veterinária. São Paulo: Roca, 2003. 457 p.

BANKS, WJ. Histologia veterinária aplicada. São Paulo: Manole Biomedicina, 1991. 658 p.

BARBOZA, RRD. A etnoecologia dos tatus-peba (euphractus sexcinctus (linnaeus, 1758) e tatu verdadeiro (dasypus novemcinctus linnaeus, 1758) na perspectiva dos povos do semiárido paraibano. Campina Grande: Universidade Federal da Paraiba, 2009. 178 p. [Dissertação de Mestrado de ciência e tecnologia e ambiental].

BENETTI, EJ. Estudo da mucosa da lingua e da superfície de interface epitélio-tecido conjuntivo da preguiça-de-coleira (Bradypus torquatus, Iliger, 1811), empregando os métodos de microscopia de luz e eletrônica de varredura. São Paulo: Faculdade de Medicina Veterinária e Zootecnia; Universidade de São Paulo, 2005. 106 p. [Tese de Doutorado em Anatomia dos Animais domésticos e Silvestres].

CIUCCIO, M., ESTECONDO, S. and CASANAVE, EB. Scanning electron microscopy study of the dorsal surface of the tongue of Dasypus hybridus (Mammalia, Xenarthra, Dasypodidae). International Journal Morphology, 2010, vol. 28, n. 2, p. 379-384.

DALPONTE, JC and TAVARES FILHO, JA. Diet of the yellow armadillo, Euphractus sexcinctus, in South-Central Brazil. Edentata, 2004, n. 6, p. 37-41.

DU TOIT, DF. The tongue: structure and function relevant to diase and oral health. South-African Association Dentistry Journal, 2003, vol. 58 , n. 9 , p. 375-383.

FISCHER, PF., PETROCHI, DL., SANTOS, AV., SOUZA, J., PINZON, PW. and ARALDI, DF. Manejo nutricional da subordem Xenarthra. In Anais do Seminário Interistintucional de Ensino Pesquisa e Extensão, 2011. Santa Cruz do Sul: Universidade no Desenvolvimento Regional, 2011. 4 p. [Resumos]. 
HIB, J. Di Fiore Histologia: texto e atlas. Buenos Aires: Librerias Yenny S.A., 2001. 513 p.

INTERNATIONAL COMITTEE ON VETERINARY GROSS ANATOMICAL NOMENCLATURE. Nomina Anatomica Veterinaria, Hannover: Editorial Committee, 2005. 166 p.

JUNQUEIRA, LC. and CARNEIRO, J. Histologia básica. Rio de Janeiro: Guanabara Koogan, 2005. 556 p.

MCDONOUGH, CM. and LOUGHRY, WJ. Behavioral ecology of armadillos. In VIZCAÍNO, SF. and LOUGHRY, WJ. (Eds.). The biology of the Xenarthra. Gainesville: University Press of Florida, 2008. p. 281-293.

MCNAB, BK. Physiological convergence amongst ant-eating and termite-eating mammals. Journal of Zoology, 1984, vol. 203, n. 1, p. 485-510.

MEDRI, IM., MOURÃO, G. and MARINHO-FILHO, J. Morfometria de Tatu- Peba, Euphractus sexcintus (Linnaeus, 1758), no pantanal de Nhecolândia, MS. Edentata, 2009, vol. 8, n. 10, p. 35-40.

MENEZES, LT., KAMINISHI, APS., VIEIRA, LG., OLIVEIRA, SRP., FERREIRA, CH., BELETTI, ME. and SANTOS, ALQ. Morfologia das papilas linguais de coelhos Oryctolagus cuniculus (Lagomorpha: Leporidae). Biotemas, 2013, vol. 26, n. 2, p. 163-173.

MORAES, JO., WATANABE, IL. and KONIG JUNIOR, B. Scanning electron microscopy of the lingual mucosa of the ninebanded armadillo, Dasypus novemcinctus. Annals of Anatomy, 1994, vol. 176 , n. 4 , p. 357-361
NASCIMENTO, JL. and CAMPOS, IB. Atlas da fauna brasileira ameaçada de extinção em unidades de conservação federais. Brasília: Instituto Chico Mendes de Conservação da Biodiversidade, 2011. $276 \mathrm{p}$.

PEREIRA JUNIOR, HRJ. Evolução cromossômica na ordem Xenarthra. Botucatu: Universidade Estadual Paulista "Júlio de Mesquita Filho", 2007. 181 p. [Tese de Doutorado em Ciências Biológicas].

ROSS, MH. Histologia: texto e atlas. Em correlação com a biologia celular e molecular. Rio de Janeiro: Guanabara Koogan, 2008. 1008 p.

SMITH, KK. and REDFORD, KH. The anatomy and function of the feeding apparatus in two armadillos (Dasypoda): anatomy is not destiny. Journal of Zoology, 1990, vol. 222, n. 1, p. 27-47.

SOUZA, AF., OLIVEIRA, VC., SANTOS, AC., ROSA, RA., CARVALHO, AF., MANÇANARES, CAF. and AMBRÓSIO, CE. Morfologia macro e microscópica da língua de quati ( Nasua nasua). Pesquisa Veterinaria Brasileira, 2012, vol. 32, n. 3, p. 271-277.

ZIMBRES, BQC. Efeito da fragmentação sobre a comunidade de tatus e tamanduás (Mammalia: Xenarthra) no Cerrado brasileiro: uma abordagem da ecologia de paisagens. Brasilia: Universidade de Brasília, 2010. 126 p. [Dissertação de Mestrado em Ecologia].

Received April 9, 2015 Accepted November 20, 2015 